\title{
Systemic Analysis of Supermarket Solid Waste Generation in Mexicali, Mexico
}

\author{
Aurora Fierro Ochoa, Moisés Galindo Duarte, Lorenzo A. Sánchez Bueno, Benjamín Valdez Salas, \\ Gisela Montero Alpírez, Michael Schorr Wiener
}

Engineering Institute, Autonomous University of Baja California, Mexicali, Mexico.

Email: aurora.fierro.ochoa@gmail.com, mgalindo@iing.mxl.uabc.mx, sanchez.bueno.alejandro@gmail.com, benjamin@iing.mxl. uabc.mx, gmontero@iing.mxl.uabc.mx,mschorr2000@yahoo.com

Received March 20 $0^{\text {th }}, 2010$; revised April 16 ${ }^{\text {th }}, 2010$; accepted April 20 2010.

\begin{abstract}
The common practice of managing solid waste (SW) generated by supermarkets in Mexicali, Mexico, consists of mixing all kinds of SW without any separation process. The concern of these actions is that does not involve some of these products to be reused or sold for recycling. The company ceases to receive an income of $\$ 3,881$ Mexican pesos as an additional benefit by the generation of approximately $5,869 \mathrm{~kg}$ of $S W$ than can be recovered in only one of its eleven branches in the city. However, the only two products that are valued by the supermarkets are wax boxes for fruits and vegetables which are sold to a company that subsequently resell them to fruit shops for reuse, and the cardboard boxes, whose weekly generation in one branch is $5,375 \mathrm{~kg}$. They are separated from the waxed boxes and placed in a compactor to form bales from 300 to $400 \mathrm{~kg}$ each and then are collected for sale to a recycling company. As for the generation of different types of plastics that can be recycled, a branch generates weekly $339 \mathrm{~kg}$. The model to simulate the generation of SW in supermarkets was performed using "system dynamics" as a tool for modeling and simulation in order to make better decisions to reduce generation of waste.
\end{abstract}

Keywords: Solid Waste, Supermarket, Model, System Dynamics

\section{Introduction}

Mexican Law defines "waste" any material or product that is solid or semisolid, which was discarded in containers or tanks and can be capable of being valued or require treatment [1].

Mexican environmental policy promotes integrated waste management through waste minimization, reuse, recycling, source separation, and recovery of materials and energy [2].

Some wastes have value for the company and are used for their benefit [3] reducing the environmental impact [4]. Disposal of these wastes in the form of garbage implies a high cost to society [5] because the places where waste can be deposited with the proper conditions of health and safety must be enabled [6].

Mexico produced 36.8 million tons of SW in 2007 and only $3.8 \%$ was recovered for recycling purposes. For 2009 , the estimated SW generation was 38.3 million tonnes of which only $68 \%$ were disposed in landfills or controlled sites [7]. The separation of re-usable materials from landfills is a common economic activity developed by people working in low economic conditions. Cur- rently, the separation takes place mainly in the informal sector of scavengers that separate the material before harvesting or before final disposal [8].

In 2007 in Mexicali were collected 773 tons of nonhazardous SW, and in 2008 were generated 850 tons. Due to the increase in municipal and commercial SW Mexicali opened about 54 thousand $\mathrm{m}^{3}$ of landfill cell in the Ejido Benito Juárez. This increased the capacity of solid waste landfill and impacted positively on the quality of life for Mexicali residents [9]. An unknown amount of SW was generated by the supermarket sector, including 35 stores [10], which are considered commercial establishments [11].

The supermarket is a commercial establishment [11], of retail [12] with a wide range of self-service products [13] designed to meet the needs of food and household products of consumers [14] with an area between 501 to $4.500 \mathrm{~m}^{2}$ [15]. Every day, tons of waste are generated in the form of packaging, plastics, nonferrous metals, organic, and others that are not managed for reuse or recycling [8].

The main issues for consideration by the supermarket sector in the recycling of materials includes: identify the 
materials are diverted from the waste stream, the reuse and recycling and the specifications of the buyers of recovered materials [16].

\section{Methodology}

The research methodology includes, characterization of SW generated in the supermarket, conceptual model design, development of a quantitative model, and simulation of the generation of SW at supermarket. The results were analyzed in an Excel spreadsheet from Microsoft and to develop and simulate the system dynamics models were used Vensim and Stella programs.

\subsection{Characterization of Solid Waste Generated in the Supermarket}

The operations manager of a regional supermarket chain located in Mexicali was interviewed in order to request permission to perform the characterization of solid waste generated. The characterization was performed in only one branch of that chain in the supermarket it was not possible to apply the sampling technique under the quartering using Standard NMX-AA-015-1985 since to homogenize the waste was difficult to obtain a uniform sample [17]. For this reason, it was decided to sample in situ adapting Standard NMX-AA-019-1985 to obtain the weight of waste in $\mathrm{kg}$ rather than the volumetric weight $\left(\mathrm{kg} / \mathrm{m}^{3}\right)$ [18]. The decision reflects the fact that supermarket managers did not agree to compact the waste and not to wait to fill a container of known volume. For this reason, the garbage was placed in the container as they would be generated.

For the waste characterization it was necessary to use a scale at the temporary disposal site within each supermarket where each head of department maintained the waste generated before being deposited in the container. The residues were separated by-product and placed on the scales and subtracting the tare. The results were recorded in a $\log$ sheet following the registration form by-products of the Standard NMX-AA-022-1985 [19].
The adequacy of the format was evaluated according to the predominance of the type of waste found and that some of the items listed in record format of the standard were absent or the amounts found were minimal [20]. Thus, all waste generated in a day of activities within the supermarket was characterized.

\subsection{Design the Conceptual Model}

The elements of the system and their relationship were determined based on the objective. These were classified according to their specific role in the structure of the system and the relations between components that generate the dynamics of the system were also identified [21].

Finally, it was drawing up the formal outline of the conceptual model using the symbology of "System Dynamics" [22]. The data used to feed the model are the initial value of solid waste in the container and cardboard in the area of receipt, the packaging for recycling fraction, the fraction of waste packages for the weekly flow of cardboard and paper, plastics, construction waste, wood, glass, garbage, organic waste, nonferrous metals, and shrinkage.

\subsection{Development of the Quantitative Mode}

In the analysis, the quantitative model of the system under study was developed using the conceptual model as a basis, and thus set the rules governing the flow of material into the system using mathematical representations.

\subsection{Simulation of the Generation of SW}

Several runs were made of the proposed models by comparing the system behavior under different conditions of interest.

\section{Results}

The regional supermarket generated $5,375 \mathrm{~kg}$ of carton (Figure 1). This material was compacted into bales of



Figure 1. Quantity of cardboard and paper in kilograms per week generated in a regional supermarket located in Mexicali, B. C. Source: characterization performed in summer 2008 


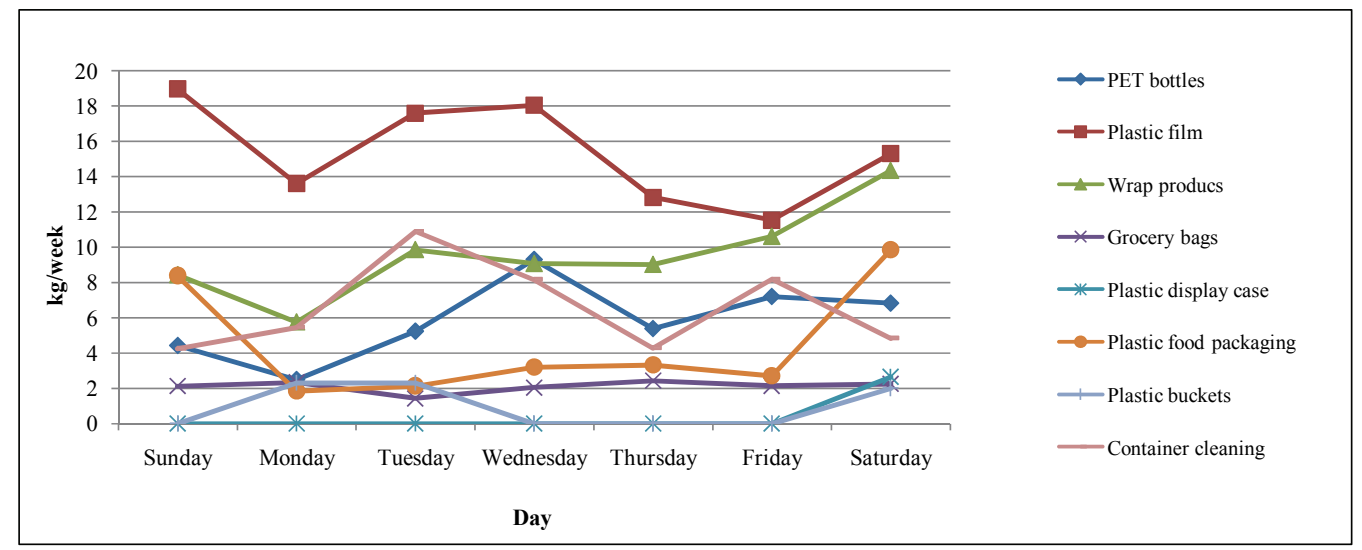

Figure 2. Quantity in kilograms per day of the week of plastics generated in a regional supermarket, located in Mexicali, Mexico. Source: characterization implemented in summer 2008

$350 \mathrm{~kg}$, and then sold to a recycling company getting an income of $\$ 2,956$ pesos per week [10].

During the week $339 \mathrm{~kg}$ of plastic, with plastic film were generated in larger quantities (Figure 2).

Causal models in Figures 3-6 show the interaction in the management of various types of SW generated in a regional supermar.

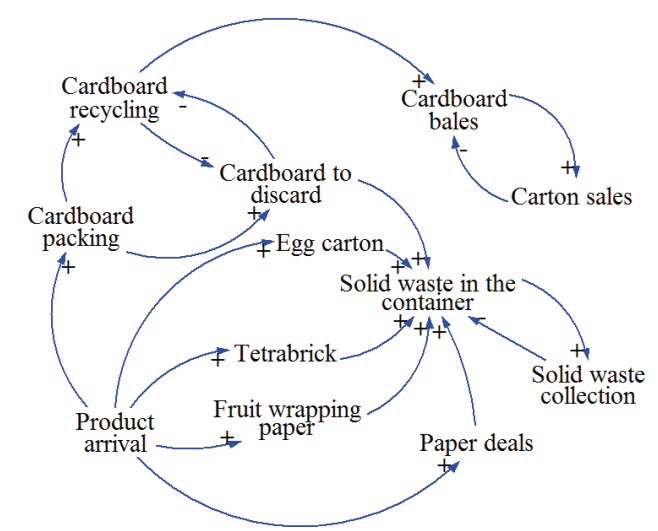

Figure 3. Causal model for paper and cardboard

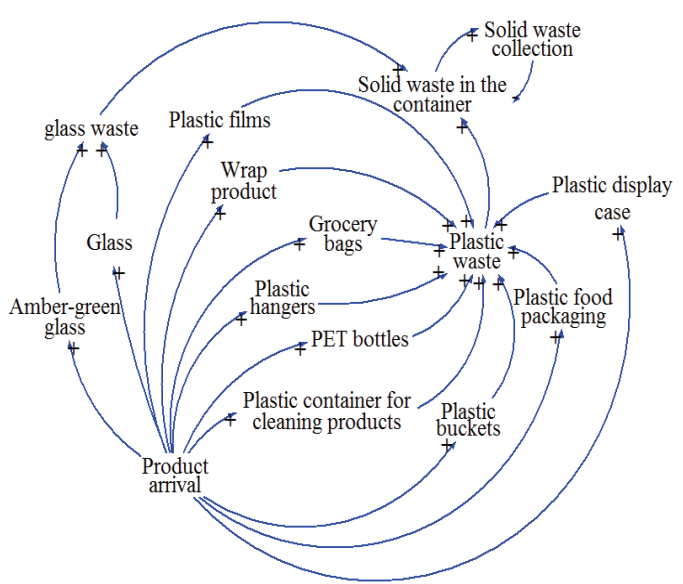

Figure 4. Causal model for plastic and glass
Figure 7 shows a general outline of the model of "system dynamics" for the management of waste generated by-product. The model represents the internal destination of the waste generated. First, the cardboard is separated for sale and only a small amount is pulled into the container because it lacks the characteristics required to be sold to a recycler. The remaining waste is indiscrimi-

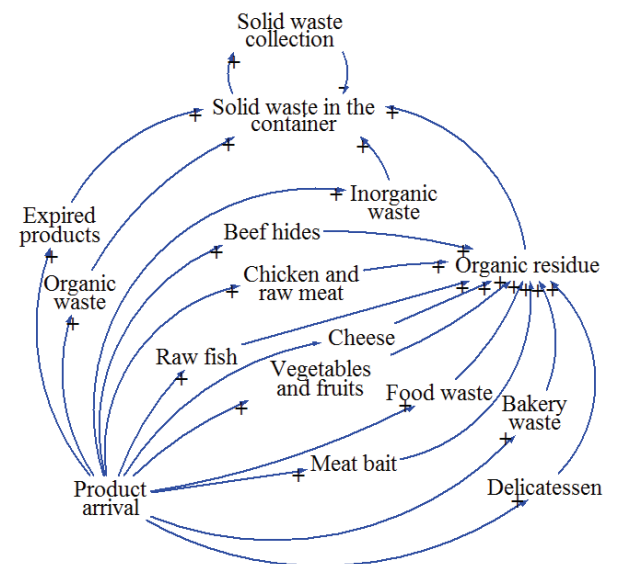

Figure 5. Causal model for waste, expired products and organic residue

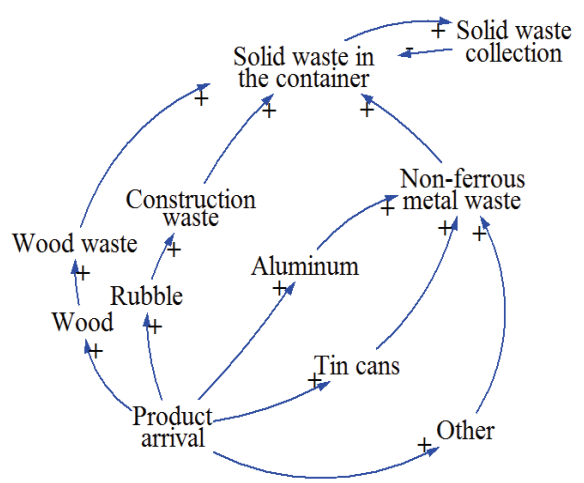

Figure 6. Causal model for wood, metal and construction waste 




Figure 7. System dynamics model of the products of waste generated in a regional supermarket chain

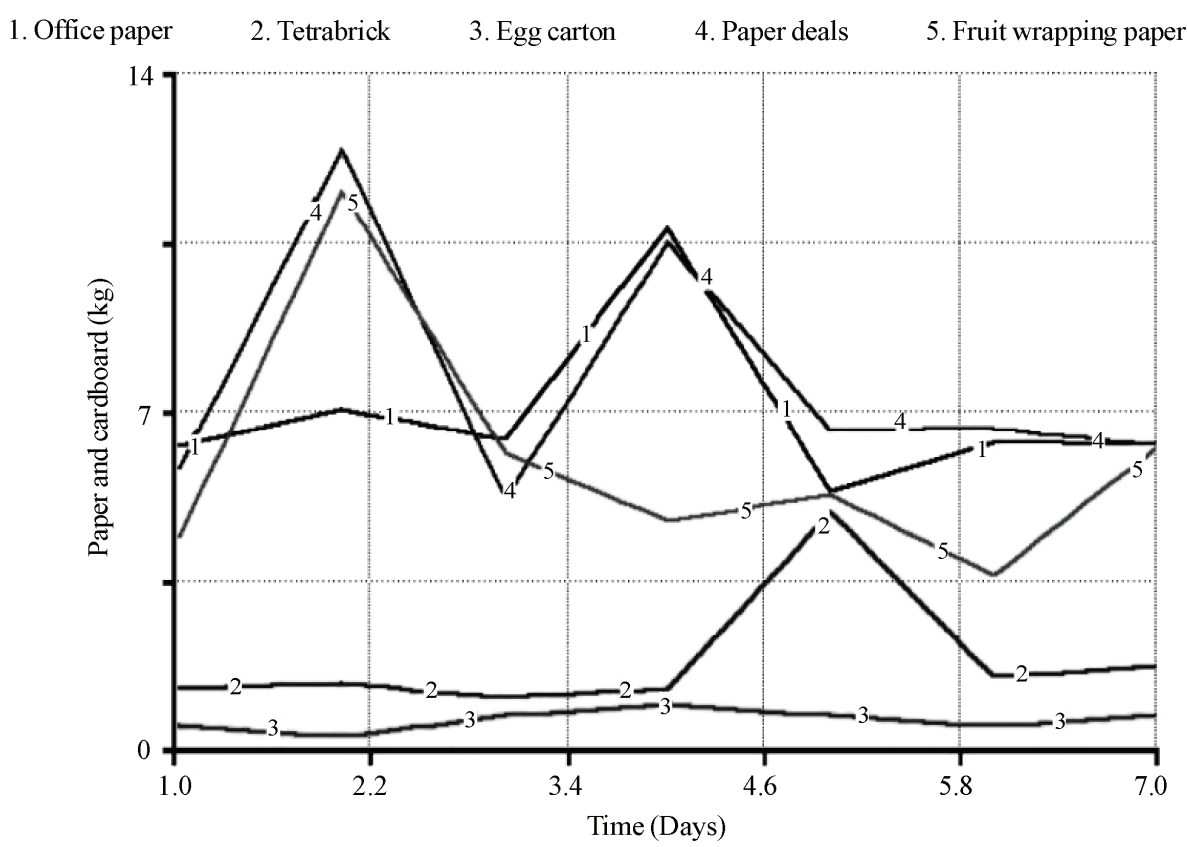

Figure 8. Simulation results for different types of generated paper 

1. PET
2. Films
3. Wrap products
4. Grocery bags
5. Plastic display case

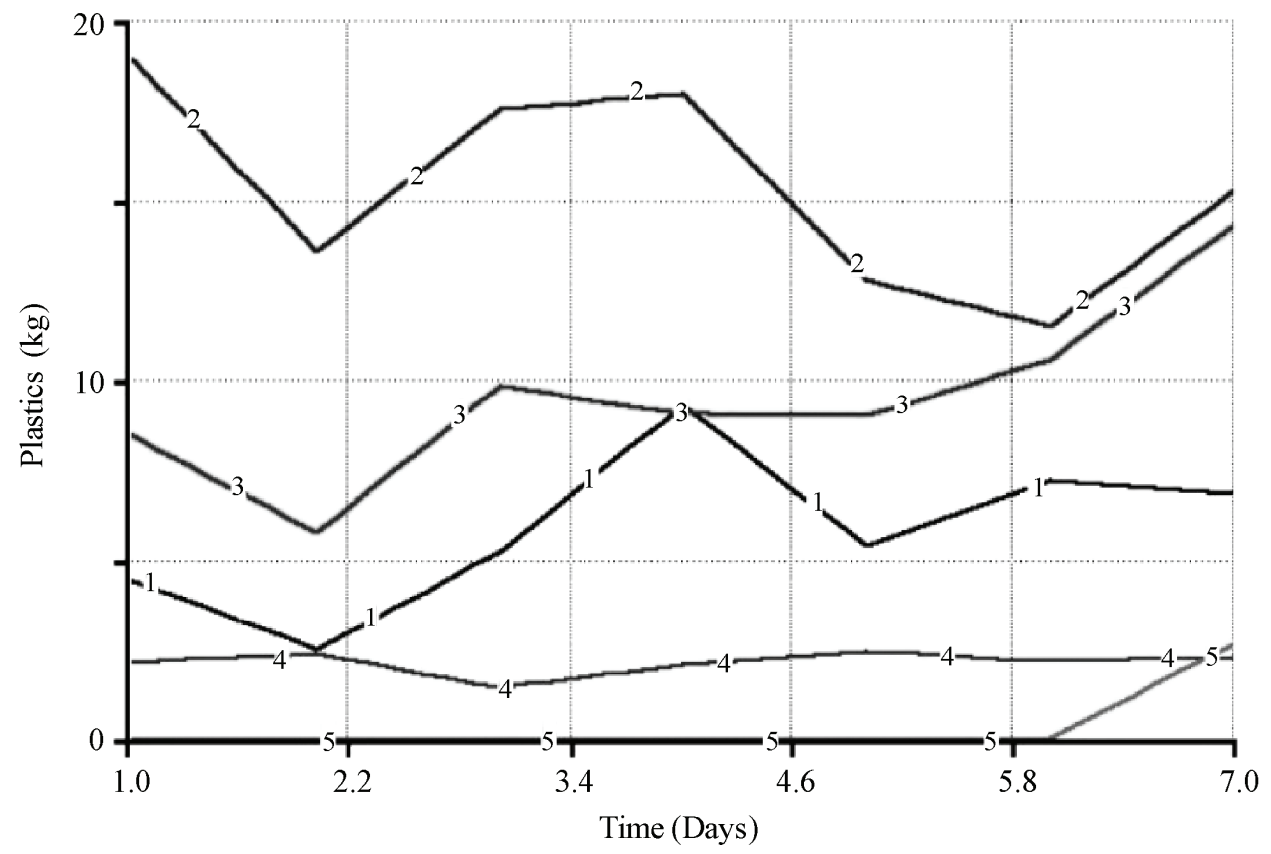

Figure 9. Simulation results for generated plastics
1. Plastic food packaging
2. Buckets
3. Container for cleaning products
4. Plastic hangers

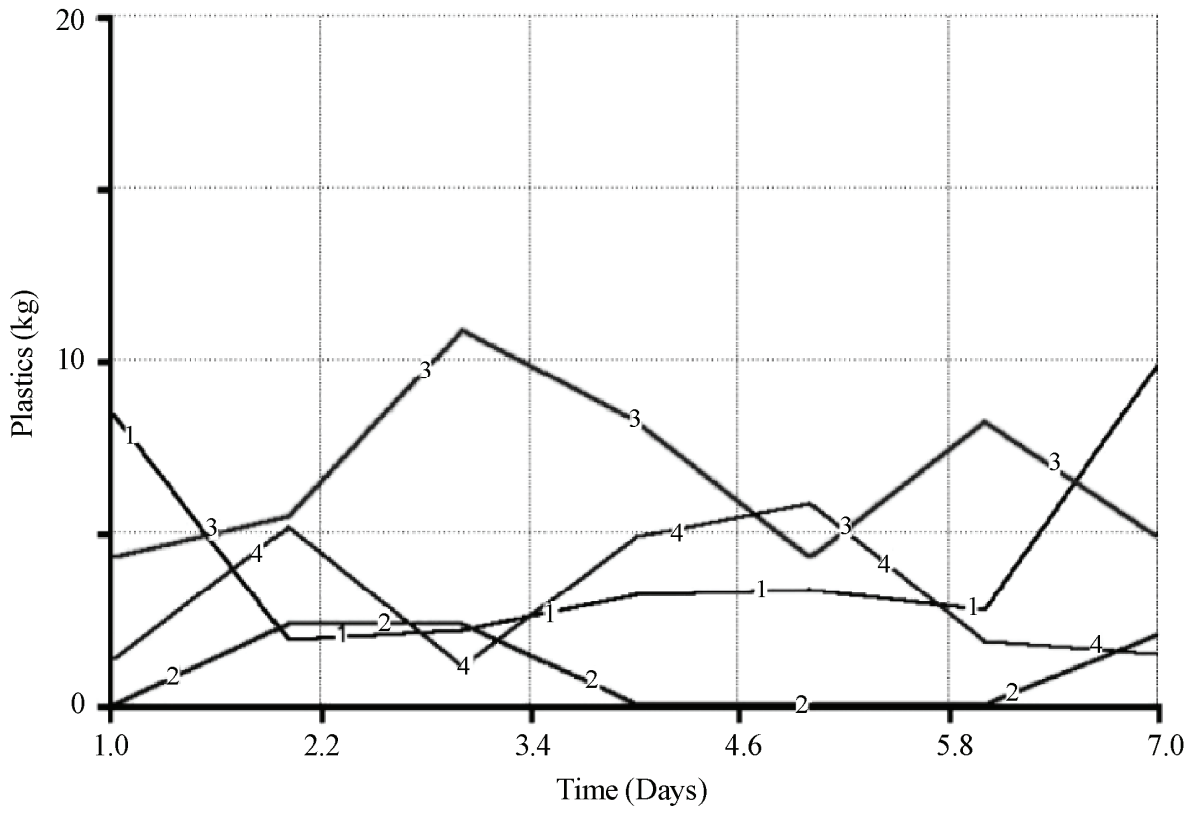

Figure 10. Simulation results for generated plastics

nately thrown into the container, instead of being separated from the source for further appreciation.

Figures 8, 9 and 10 show the simulation results using the "Stella" and can observe the dynamics of the various types of waste generated during one week. These results can be compared with those in Figures $\mathbf{1}$ and $\mathbf{2}$ obtained from the characterization in situ.

\section{Conclusions and Discussion}

Supermarkets should classify the types and quantities of solid waste being generated and also the tools that are available to separate at source, that is, they must carry out a sustainable management of waste generated as this concept is based on identification of the possible 
uses of each of the materials contained in a product, to provide from the conceptual stage the future handling of the material itself is important and appropriate choice of those providers committed to the environment [2]. Proper management of solid waste allows the company to earn additional income to cover some of their expenses.

The supermarket sector must be able to assess the environmental conflict that is generated by improper management of their waste and take part in the settlement through their involvement. They should not wait for the authorities verification, resulting in penalties and a poor image for the company. Moreover, it is the responsibility of the authorities to encourage the creation of companies engaged in the collection and recycling of packaging [7].

Using "dynamic systems" as a tool, it is possible to model and simulate the generation of solid waste in supermarkets, which allows observing the operation and behavior of each product generated. It is also possible to include additional variables that allow better decisions to reduce generation of waste.

\section{Acknowledgements}

The authors gratefully acknowledge the financial support of Consejo Nacional de Ciencia y Tecnología (CONACYT), Mexico.

\section{REFERENCES}

[1] SEMARNAT (Secretaría de Medio Ambiente y Recursos Naturales) Environmental and Natural Resources Secretary, General Law for Prevention and Integrated Waste Management, Official Newspaper of the Federation, in Spanish, Mexico, 2003.

[2] SEMARNAT (Secretaría de Medio Ambiente y Recursos Naturales) Environmental and Natural Resources Secretary, National Program for Prevention and Waste Management 2009-2012, Official Newspaper of the Federation, in Spanish, Mexico, 2 October 2009.

[3] M. Stanley, "Introduction to Environmental Chemistry," in Spanish, Reverté, 2007.

[4] G. Bernache, "When We Reach the Trash. The Impact of Environmental Degradation," in Spanish, Chata House, 2006.

[5] G. Tyler, "Environmental Science. Sustainable Development. A Comprehensive Approach," in Spanish, Thomson, 2007.

[6] E. Bono and J. A. Tomás, "Municipal Waste and Environmental Sustainability," in Spanish, Mediterranean Institute Sustainable Development, 2006.
[7] President of Mexican Republic, Second Report of Government, in Spanish, México, 2008, p. 424.

[8] X. Montagut, E. Vivas and F. García, "Supermarkets, no Thanks. Mayor Retail Chains: Impacts and Alternatives," in Spanish, Icaria, 2007.

[9] XIX Ayuntamiento de Mexicali, Second report of government, in Spanish, Mexicali B. C., 2009.

[10] A. Fierro, M. Galindo, B. Valdez and G. Montero, "Economic Viability in the Separation of Solid Waste in the Supermarket Sector in Mexicali," in Spanish, National Congress of Graduate Students of the Institute of Engineering, UABC, Mexicali, B. C., November 2009.

[11] J. C. Buerruezo, "The Modern Management of Retail. The Practical Success of The Store," in Spanish, ESIC, 2003.

[12] C. W. Lamb, J. Hair and C. Mc Daniel, "Marketing," Thomson, 2006

[13] S. Miquel, F. Parra, C. Lhermie and M. J. Miquel, "Commercial Distribution," in Spanish, ESIC, 2006.

[14] P. Kotler and K. K. Lane, "Marketing Management," in Spanish, Pearson, 2006.

[15] ANTAD (Asociación Nacional de Tiendas de Autoservicio y Departamentales de México) National Association of Supermarkets and Department Stores in Mexico, Partners directory ANTAD, in Spanish, 2008.

[16] C. Ponte, "Integrated Solid Waste Management: Recycling Program," in Spanish, Research Journal, Vol. 32, No. 63, January 2008, pp. 173-200.

[17] SECOFI (Secretaría de Comercio y Fomento Industrial) The Secretariat of Commerce and Industrial Development, Mexican Norm NMX-AA-015-1985, Official Newspaper of the Federation, México, 1985.

[18] SECOFI (Secretaría de Comercio y Fomento Industrial) The Secretariat of Commerce and Industrial Development, Mexican Norm NMX-AA-019-1985, Official Newspaper of the Federation, México, 1985.

[19] SECOFI (Secretaría de Comercio y Fomento Industrial) The Secretariat of Commerce and Industrial Development, Mexican Norm NMX-AA-022-1985, Official Newspaper of the Federation, México, 1985.

[20] O. Buenrostro, G. Bernache, S. Cram and G. Bocco, "Analysis of the Generation of Solid Waste in Municipal Markets of Morelia, MÉXico," in Spanish, International Journal of Environmental Pollution, Vol. 15, No. 001, 1999, pp. 27-32.

[21] M. García, "Modeling Course in Ecology and Human Resource Management," in Spanish, Universitat Politècnica de Catalunya, 1999.

[22] W. E. Grant, E. K. Pedersen and S. L. Marin, "Ecology and Natural Resource Management: Systems Analysis and Simulation," John Wiley \& Sons, 1997. 